\title{
IDENTIFICATION OF MUTATION IN THE BEMISIA TABACI (GENN.) PARA SODIUM CHANNEL GENE ASSOCIATED WITH RESISTANCE TO PYRETHROIDS

\author{
153
}

Central Agricultural Pesticides Laboratory, ARC, Dokki, Giza

(Manuscript received 18 August 2009)

\begin{abstract}
Mechanism of resistance to lambda-cyhalothrin in highly resistant Bemisia tabaci strain can be explained by the voltagegated sodium channel which is the primary target site of pyrethroid insecticides. The super knockdown resistance (super-kdr) to pyrethroids is caused by changes at specific sites on the para-type sodium channel protein domain II (IIS4-6). The B. tabaci para type sodium channel gene was RT-PCR amplified from lab-strain (reference), Parent (first generation after treatment with the insecticide) and generation thirteen after treatment was considered. The mechanisms of resistance to Lambda-cyhalothrin (Karat $20 \% \mathrm{EC}$ ) in a Q biotype, highly resistant Bemisia tabaci strain. Analysis of the sequence of the IIS4-IIS6 region of the para sodium channel gene of lab-strain, Parent and resistant strain (G13) revealed two amino acid replacements compared to that of the SUD-S susceptible strain. One is the leucine to isoleucine substitution at position 925 (L925I) and allele r1-Q1 (GenBank accession no. DQ205206) has identical intron sequences with samples of parent and lab-strain, other is a novel kdr resistant mutation for $B$. tabaci, a threonine to valine substitution at position (T929V) and alleles r2-Q1 (GenBank accession no DQ205207) has identical intron sequence with $\mathrm{G}_{13}$..

Keywords: Bemisia tabaci, sodium channel gene, insecticide resistance, pyrethroids
\end{abstract}

\section{INTRODUCTION}

The whitefly, Bemisia tabaci is one of the most serious and key against pests of numerous crops worldwide. The ability of $B$. tabaci to develop resistance to insecticides after only a few applications makes its control problematic in the long term (Denholm,I. et al 1998)

For the past thirty years, B.tabaci control in Egypt has been based almost exclusively on conventional insecticides such as organophosphates, pyrethroids and carbamates. Little work quantifying resistance in B.tabaci in Egypt has been published, but it is clear that, by the late 1980s, at least some of these broad-spectrum insecticides were failing in some situations, the pyrethroid cypermethrin, lost its efficacy during 1989 and 1990, severe resistance to organophosphate and pyrethroids in B.tabaci from Egyptian cotton fields were established (Abdallah 1991). More recent data on insecticide efficacy from field trials on cotton shows that many traditional 
insecticides are no longer effective (Sobiha et al.,1997) and 10 to 12 insecticide applications per season are now common in the cotton crop.

Insecticide resistance selection is even more marked on vegetable crops, where the risk of whitefly mediated virus transmission (particularly in tomatoes) has led farmers to apply organophosphate and/or pyrethroid insecticides two or three times per day (Hafez El-Kady \& Gregor J.D. 2003). Monitoring high resistance levels to several insecticide classes in field $B$. tabaci populations from different governorates in seasons 2000 and 2001, particularly pyrethroids and organophosphates, resistance factors to the pyrethroid lambda-cyhalothrin was up to 1161.54 fold (Farghaly 2005).

Resistance to pyrethroids in B.tabaci has been associated with enhanced detoxification by oxidative and hydrolytic pathways. In addition, target site insensitivity was recently implicated in B. tabaci pyrethroid resistance, (Morin et al., 2002). Although the kdr mutation L1014F found in many important agricultural pests, (Soderlund and Knipple 2003) has not been detected in the sweet potato whitefly, two mutations in the IIS4-5 linker of B.tabaci sodium channel gene, a methionine to valine substitution at position 918 (M918V) and a leucine to isoleucine alteration at position 925 (L925I) conferred high levels of fenpropathrin resistance in B. tabaci strains isolated from Arizona, (Morin et al., 2002). A third sodium channel resistance mutation, a threonine to valine substitution at position 929 (T929V), was implicated with pyrethroid resistance, in a highly resistant B. tabaci strain (GRMAL-RP) isolated from Crete, Carboxylesterase (COE) - and cytochrome P450 dependent monoxygenase-based detoxification was also implicated in pyrethroid resistance in GRMAL-RP, (Bass et al., 2004)

In the present study, the level of resistance to lambda-cyhalothrin was estimated in population of B.tabaci. Subsequent insecticide selection was carried out to build up resistance, and identification of mutations within the voltage-gated sodium channel gene. This information is fundamental to an understanding of insecticide resistance and for the development strategies to reduce the risk for lambdacyhalothrin. 


\section{1-Insecticide used}

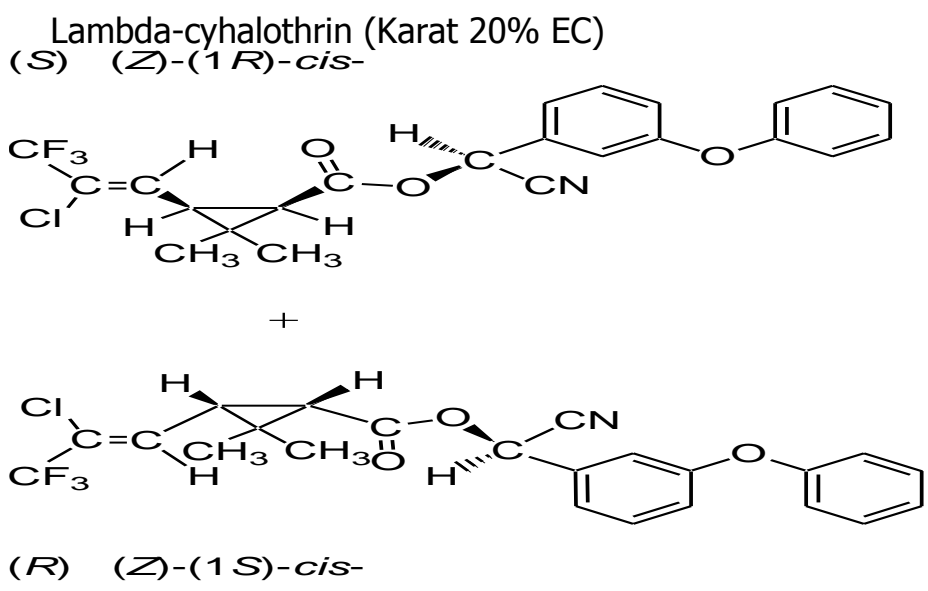

\section{2-Bemsia tabaci strain}

Field strain of B.tabaci was collected from Behera governorate (2000) and maintained without insecticide selection pressure for more than 8 years in the lab of Central Agricultural Pesticides Laboratory, department of rearing standard insects. Resistant-strain derived from the Lab-strain was selected with lambda-cyhalothrin for 13 generations (127.08 fold) as shown in table (2).

\section{3-Bioassay}

The bioassay method for obtaining concentration-response regressions lines was described by (Prabhaker et al., 1985) with some modification, attached cotton leaves were dipped for $5 \mathrm{sec}$. in $100 \mathrm{ml}$ of the desired concentration of each insecticide and allowed to dry, the treated leaves were laid on a thin layer of $2 \%$ agar in small cage and then twenty adults were transferred into the cage by an aspirator. Mortality was recorded 24 and $48 \mathrm{hr}$ after treatment. Six concentrations At least were tested for each insecticide, each test was replicated on five different. Results were expressed as percentage mortalities, corrected using (Abbott formula, 1925).

\section{4-Selection pressure}

The population of the resistant-strain which consisted of many thousands was subjected to laboratory selection pressure with insecticide, at a level producing 30\% mortality to the adult stage. The level of developing resistance was determined at generations 3, 6, 9 and 13, Resistance ratio (RR) was determined by dividing the $\mathrm{LC}_{50}$ of the R-strain by the $\mathrm{LC}_{50}$ of lab-strain.

\section{1-RT-PCR analysis of $B$. tabaci sodium channel gene sequences}


The IIS4-5 region of the B.tabaci para-type sodium channel gene was initially amplified by reverse transcriptase-mediated PCR (RT-PCR). Total RNA was extracted from susceptible strain, parent types and generation thirteen ( $\mathrm{S}, \mathrm{P}$ and $\mathrm{G} 13$ ). In each sample, 100 adults were homogenized according to the manufacturer's instructions. One RNA sample was produced for each sample. First strand cDNA was synthesized from total RNA $(3 \mu \mathrm{g})$ by reverse transcriptase (superscript III, RNase $\mathrm{H}^{-}$, ready togo RT-PCR kit Pharmacia, Aniasham) with oligodT ( $20 \mu \mathrm{M})$ as a primer, according to the supplier recommended protocol. The cDNA fragments served as templates for subsequent PCR amplification using the forward primer kdr-1 (5' GCCAAATCCTGGCCAACT $3^{\prime}$ ) and reverse Kdr-4 (5' GAAATTACTCAGCAACAACGC $3^{\prime}$ ). The thermal conditions were : denaturation at $94^{\circ} \mathrm{C}$ for 3 min followed by 35 cycles of $94{ }^{\circ} \mathrm{C}$ for $30 \mathrm{~s}, 55^{\circ} \mathrm{C}$ for $30 \mathrm{~s}$ and $72{ }^{\circ} \mathrm{C}$ for $1 \mathrm{~min}$, and final extension at $72{ }^{\circ} \mathrm{C}$ for 10 $\min$.

\section{2-Sequence analysis}

The presence or absence of the L925I and T929V mutation in individual B.tabaci adult was analyzed using the manufacturer recommendations (Ahmadian et al., 2000). The gene fragments of interest were amplified using the primers Bemisia Na-channel pyro $f$ biotin (5' TGGCCAACTTTGAATCTGTT $3^{\prime}$ ) and Bemisia Pyro $r$ (5' GCATTCCCATCACAGCAAAA $3^{\prime}$ ) that amplify a 112 bp fragment comprising the L925I and the T929V mutations.

\section{3-Phylogenetic analysis}

To determine the phylogenetic relationship between resistant and susceptible allel sequences, the sequences were aligned using the (Bioeditver 201) for maximum likelihood analysis. Maximum likelihood analysis were performed by the branch and bound search, with the tree bisection and reconnection option (TBR).

\section{RESULTS}

\section{1- RT-PCR amplification of the nS4-6 region of the $B$. tabaci para-type sodium channel gene.}

The $\Pi$ S4-5 region of the $B$. tabaci para-type sodium channel gene was RT-PCR amplified from lab-strain (reference), Parent (first generation after treatment with the insecticide) and generation thirteen. Alignment of the different CDNA clones revealed the presence of four mismatches and five different sequences (Table 1 and Fig.1).

Compare with susceptible laboratory strain (Sudan) at position 61, cDNA clones from both lab and parent had $A$ nucleotide instead of $T$ nucleotide the second substitutions, $T$ nucleotide instead of A nucleotide at position 63, caused a L925I substitution (sodium channel numbering follows the housefly para-type sodium 
channel protein sequence EMBL X96668), and were designated as r1-Q1 (GenBank accession no. DQ205206). The L925I mutation was previously identified in a B biotype strain from Arizona and found the linked to synergized pyrethroid resistance (Morin et al., 2002). They identified in a $Q$ biotype strain (Alon et al., 2006). The third and fourth substitution, $A$ to $C$ at position 73 and $C$ to $T$ at position 74 , occurred only in cDNA clones from lab-strain and parent type. These substitutions cause a threonine to leucine substitution at position 929 (T929L). But $13^{\text {th }}$ generation had G instead of A at position 73 and $T$ instead of $C$ at position 74. These substitutions cause a threonine to valin (T929V). An identical mutation was recently associated with pyrethroid resistance in cat flea (Bass et al., 2004, Alon et al., 2006) which agrees with our results. The cDNA sequence harbouring the T929V mutation was designated as r2-Q1 (GenBank accession no. DQ205207). The two wild-type sequences lacking the L925I and T929V mutations, but differing in the codon usage of V981, were designated as s-B and s-Q (GenBank accession nos. AJ440727 and DQ205204, respectively). The five identified cDNA sequence had the kdr mutation L1014Q and L1014K [lab-strain, parent and generation $13^{\text {th }}$ respectively in $\Pi$ S4-6 region]. 


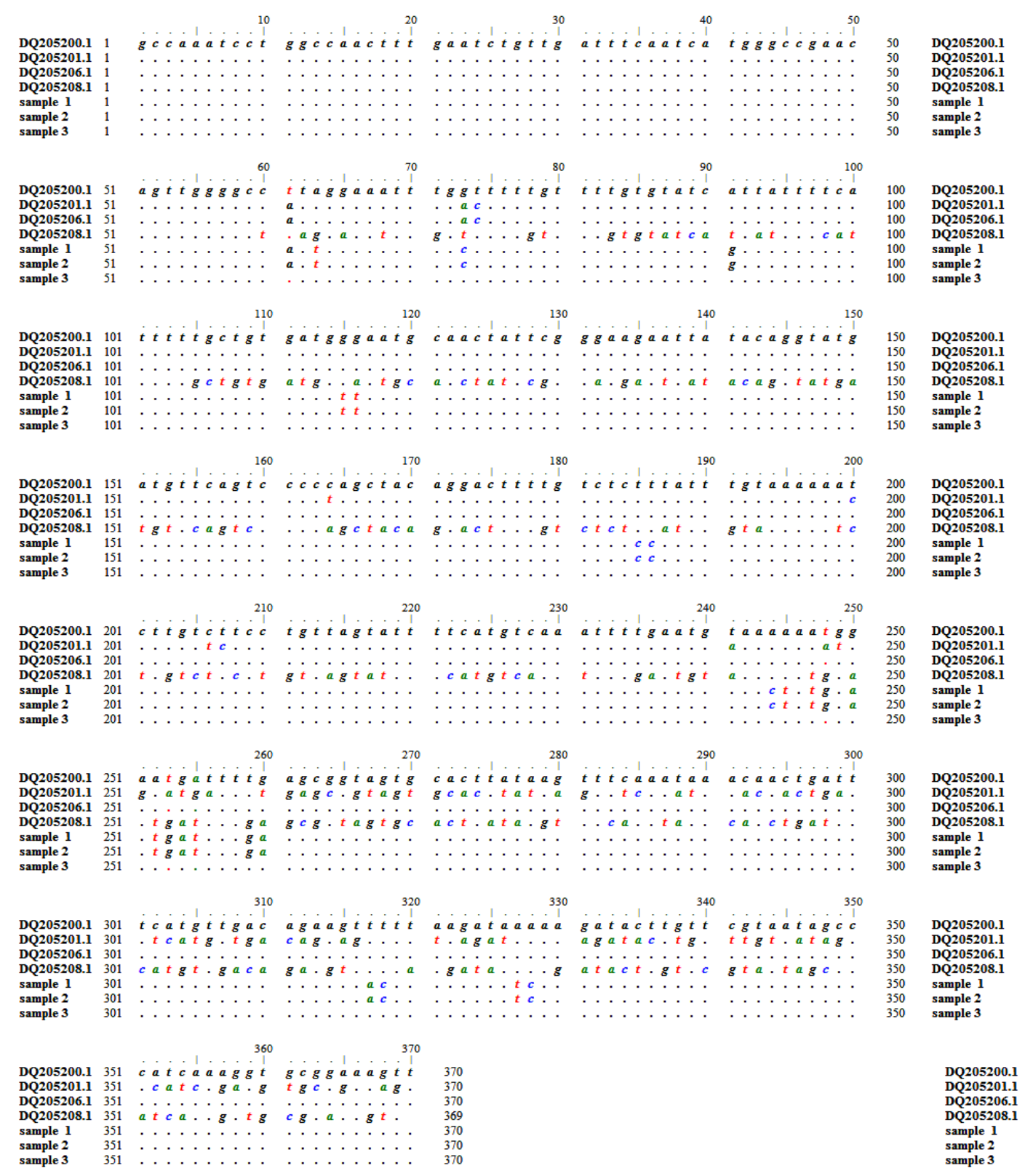

Fig. 1. Nucleotide sequence of the IIS4-6 region of B. tabaci para-type sodium channel gene, amplified from the (susceptible strain, parent type and generation thirteen). The identified cDNA sequences differed by nucleotide substitutions at positions 61 (L925I) and 73 (T929V).The position of the kdr (L1014) and super kdr (M918) mutation sites, found in other insects but not in B.tabaci . 
Table 1. Nucleotide variation in resistant generation parent and susceptible lab-strain of B.tabaci para-type sodium channel alleles. The sequences span last 145 bp of the first exon and the complete sequence of the first intron in the nS4-6 region

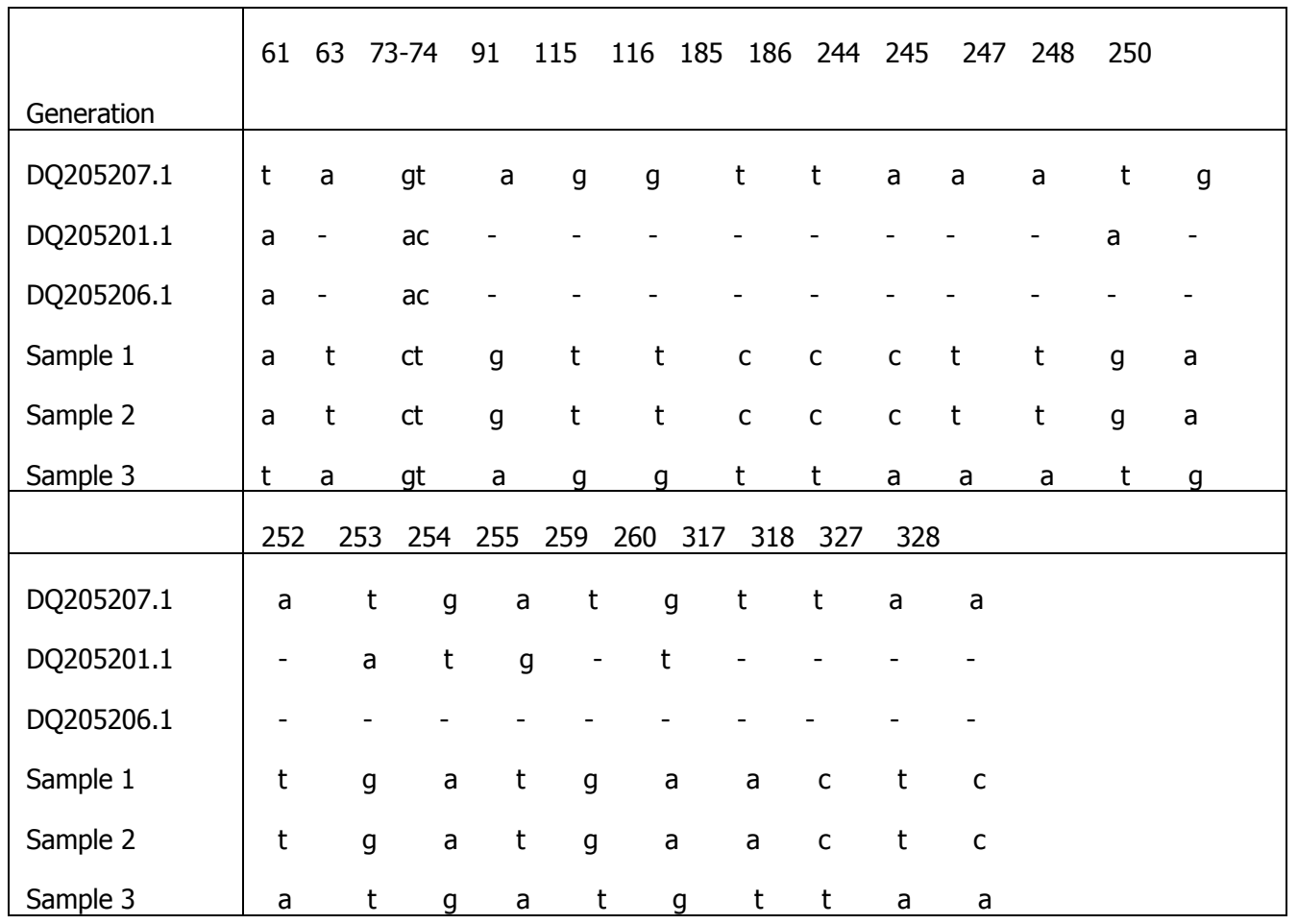

\section{2-The role of $L 925 I$ and $T 929 \mathrm{~V}$ in resistance}

To examine the association between the L925I and T929V mutations and resistance to pyrethroids, bioassay of different generations of resistant strain: $G_{3}$, $G_{6}$, $\mathrm{G}_{9}$ and $\mathrm{G}_{13}$ was carried out (Table 2).

Table 2. Rate of resistance development for Lambda-cyhalothrin in whitefly B.tabaci during selection for 13 generations.

\begin{tabular}{|c|c|c|c|}
\hline \multirow{2}{*}{ strain } & \multicolumn{3}{|c|}{ Karate selected 13 generations strain } \\
\cline { 2 - 4 } & Slope \pm EC & LC50Ppm(95\%FL) & RR* \\
\hline \multirow{2}{*}{ Lab.strain } & $1.39 \pm 0.43$ & $6.86(3.43-11.39)$ & ---- \\
\hline Parent & $1.12 \pm 0.44$ & $5.36(1.77-13.53$ & 0.78 \\
\hline$G_{3}$ & $2.86 \pm 0.82$ & $21.10(--------)$ & 3.10 \\
\hline$G_{6}$ & $1.63 \pm 0.24$ & $30.63(23.78-41.28)$ & 4.46 \\
\hline$G_{9}$ & $1.12 \pm 0.37$ & $98.94(27.02-215.42)$ & 14.42 \\
\hline$G_{13}$ & $1.45 \pm 0.19$ & $127.08(97.02-175.51$ & 18.52 \\
\hline
\end{tabular}

$\mathrm{RR}^{*}$ (Resistance ratio) $=\mathrm{LC}_{50}$ of the resistant strain $/ \mathrm{LC}_{50}$ of Lab-strain 
Table 3. Mutation found in the transmembrane segment IIS4 of the para sodium channel gene in different strains of B. tabaci

\begin{tabular}{|c|c|c|c|}
\hline Strain & Description & $\begin{array}{l}\text { Sequence at position } \\
\qquad 925^{\mathrm{a}}\end{array}$ & $\begin{array}{l}\text { Sequence at } \\
\text { position } 929^{\mathrm{a}}\end{array}$ \\
\hline SUD-S ${ }^{b}$ & Lab susceptible (Sudan) & TTA Leucine & ACT threonine \\
\hline $\begin{array}{l}\text { Sample1 } \\
\text { Parent }^{\mathrm{c}}\end{array}$ & $\begin{array}{l}\text { Pyrethroid resistant lab strain } 1^{\text {st }} \\
\text { generation }\end{array}$ & ATT isoleucine & CTT leucine \\
\hline $\begin{array}{l}\text { Sample2 } \\
\text { susceptible }^{c}\end{array}$ & Susceptible lab strain & ATT isoleucine & CTT leucine \\
\hline $\begin{array}{l}\text { Sample3 } \\
\text { Generation13 }\end{array}$ & $\begin{array}{l}\text { Pyrethroid resistant lab strain } \\
13^{\text {th }} \text { generation }\end{array}$ & TTA Leucine & $\mathrm{GTT}^{\mathrm{d}}$ Valin ${ }^{\mathrm{e}}$ \\
\hline GRMAL-RP ${ }^{d}$ & Pyrethroid resistant from Crete & ATA $^{\mathrm{e}}$ Isoleucine $^{\mathrm{e}}$ & $\mathrm{GT}^{\mathrm{d}}$ Valin ${ }^{\mathrm{e}}$ \\
\hline
\end{tabular}

a Numbering of amino acid residues follows translation of Musca domestica sodium channel gene (X96668).

b Sequences reported by Morin et al.,( 2002 )

c This study

d Sequences reported by Emmanouil et al.,( 2006 )

e Replacements occurred in single haplotypes

which has the $\mathrm{r2-Q} 1$ carrying the T929V mutations), parent and lab-strain which has both the r1-Q1 sequences (carrying L925I mutations) (Table 3) and extracted RNA from lab-strain (s), parent $(p)$ and three generations of resistant strain $\left(G_{4}, G_{9}\right.$ and $\left.G_{13}\right)$ which appeared bands with M.W. 399, 417, 416, 418 and 420 KDa respectively. (Table 4 and fig. 2)

The role of L925I has been well documented in B. tabaci pyrethroid resistance (Morin et al., 2002), the second mutation, threonine (ACT)-valine (GIT) replacement at amino acid 929 (T929V) identified in the $\mathrm{G}_{13}$ pyrethroid resistant strain (Table 3), is the same kdr resistance mutation previously reported in the cat flea Centocephalids felis (Bass et al., 2004) and pyrethroid resistance from Crete in the B. tabaci ( Roditakis et al., 2006) the role of the T929V in pyrethroid resistance has been established by site directed mutagenesis and functional expression studies in Drosophila (Atkinson, 2002). 


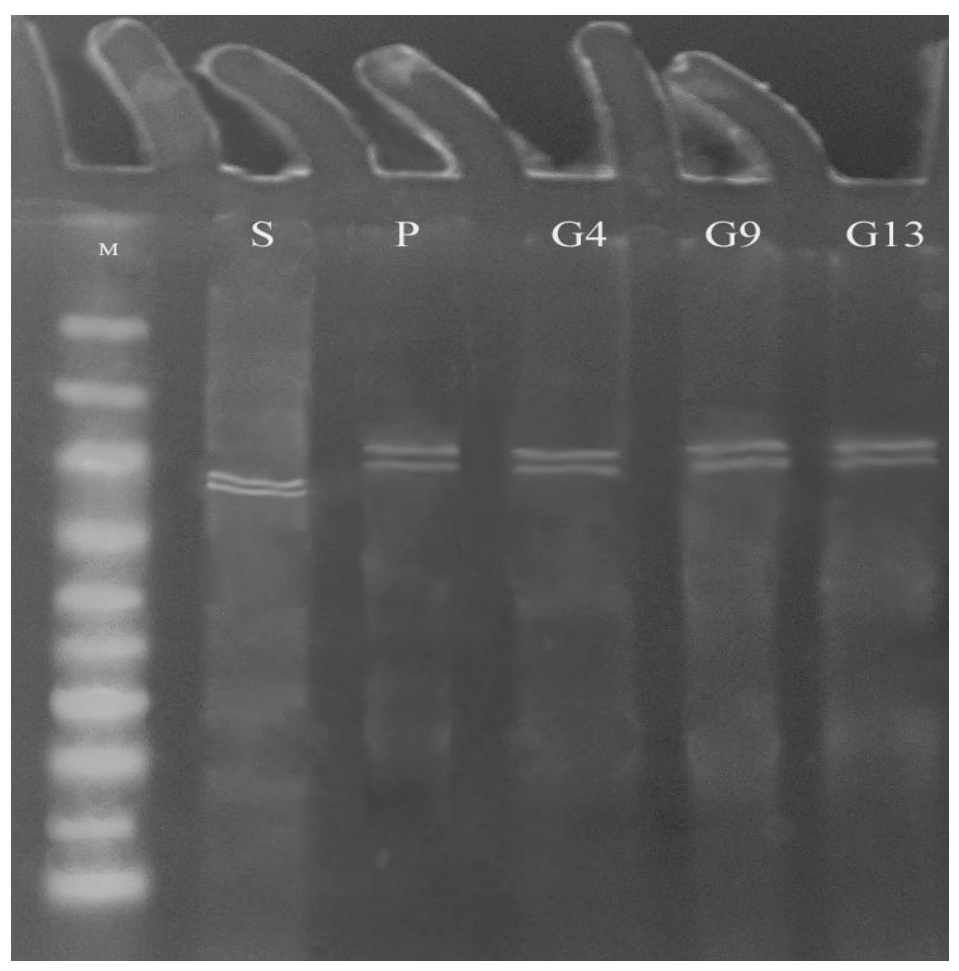

Fig. 2. Gel analysis of RT-PCR amplification using Kdr-1 forward and Kdr-4 reverse. The wild-type allele was amplified from three generations. DNA was extracted from 100 whitefly laboratory-strain (s), three generations of resistant strain $\left(G_{4}, G_{9}, G_{13}\right)$. The position of the amplified PCR fragment was (370 bp)

Table 4 . Molecular weight of RNA bands for different samples of resistant strain

\begin{tabular}{|l|c|}
\hline \multicolumn{1}{|c|}{ Generation } & Molecular weight \\
\hline Lab. strain & 399 \\
Parent & 417 \\
Generation 4 & 416 \\
Generation 9 & 418 \\
Generation 13 & 420 \\
\hline
\end{tabular}

\section{4- Nucleotide variation in the first axon and first intron of domain nS4-6}

In the Q-biotype, it is found that two resistant alleles $\mathrm{r} 2-\mathrm{Q} 1$ (GenBank accession nos. DQ205207) has identical intron sequence with $G_{13}$. The overall nucleotide variation was 0.000. and allele r1-Q1 (GenBank accession no. DQ205206) has identical intron sequences with samples of parent and lab-strain. The overall nucleotide variation for samples was 0.000 but the samples differs from r1-Q1 by 22 nucleotide substitutions (table 1). The overall nucleotide variation for samples with r1-Q1 (GenBank accession no. DQ205206) was 0.066 . 


\section{5- Phylogenetic analysis}

Phylogenetic analysis using maximum likelihood is shown in (Table 5 and Fig 3). The value of similarity between $\mathrm{G}_{13}$ and $\mathrm{r2-Q1}$ (GenBank accession no. DQ205207) was 100.00 . While the value of similarity for sample1, sample2 and r1-Q (GenBank accession no. DQ205206) was $93.38 \%$ because the two samples differs from allele r1$\mathrm{Q}$ by 22 nucleotide substitution .(Table 1 ).

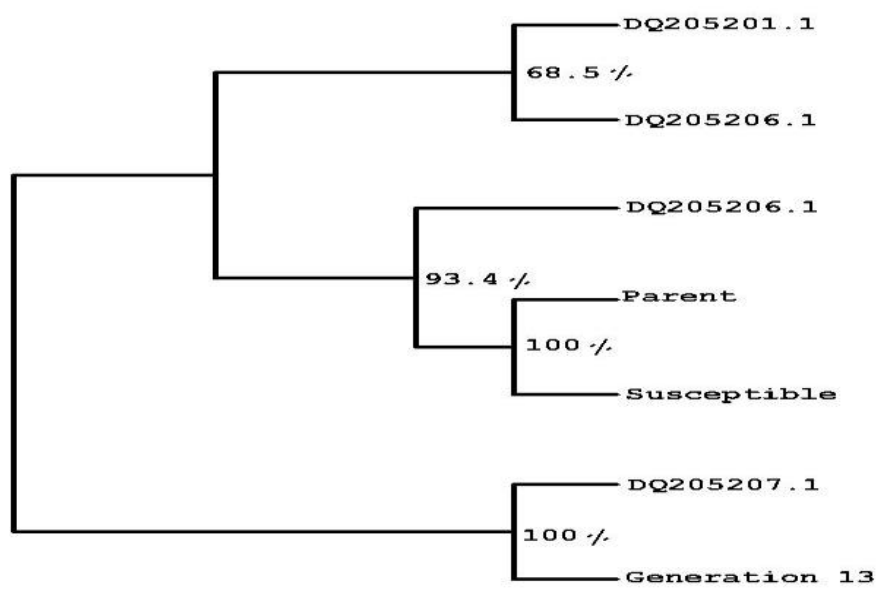

Fig 3. Maximum likelihood analysis of resistant and susceptible allele Sequences produced from the first exon (145bp) and first intron in ( $730 \mathrm{bp}$ ) the IIS4-6 domain of the B.tabaci para-sodium channel gene. Analyses were performed by the branch and bound search, with the tree bisection and reconnection option (TBR).

Table 5. Estimated similarity for allele sequences produced from the first exon (145 bp) and first intron ( $730 \mathrm{bp}$ ) in the IIS4-6 domain of the B. tabaci paratype sodium channel gene.

\begin{tabular}{|c|c|c|c|c|c|c|}
\hline & DQ205207 & DQ205201 & DQ205206 & Sample1 & Sample2 & Sample3 \\
\hline DQ205207 & 100.00 & ------- & -------- & ------- & ------- & ------ \\
\hline DQ205201 & 67.10 & 100.00 & -------- & ------- & ------- & ------ \\
\hline DQ205206 & 99.18 & 68.45 & 100.00 & ------ & ------ & ------ \\
\hline Sample1 & 93.38 & 59.42 & 93.38 & 100.00 & ------- & ------ \\
\hline Sample2 & 93.38 & 59.42 & 93.38 & 100.00 & 100.00 & ------ \\
\hline Sample3 & 100.00 & 67.10 & 99.18 & 93.38 & 93.38 & 100.00 \\
\hline
\end{tabular}




\section{DISCUSSION}

Point mutations in the insect para sodium channel gene that reduce the sensitivity to pyrethroids have been identified in several insect species. Most studies have focused on the IIS4-5 region, using degenerate primers designed from conserved sequences in these membrane-spanning segments (Martinez-Torres et al., 1997). Using this strategy, we amplified from B. tabaci (a resistant lab strain from Egypt) the cDNA fragment spanning the II4-6 region. Through cloning and sequencing we identified two mutations, (L925I and T929V). The two mutations have been previously reported in the GRMAL-RP (a resistant lab strain from Crete) of $B$. tabaci (Roditakis et al., 2006). The L925I mutation was reported by (Morin et al., 2002), while functional expression studies in oocysts showed that it is able to reduce channel sensitivity to deltamethrin by over 2000-fold (Atkinson 2002). In contrast, the mutation at position 918 (methionine), which was associated with pyrethroid resistance in a laboratory selected whitefly strain [but not in pyrethroid-resistant fieldcollections from Arizona (Morin et al., 2002)] was not also found in GRMAL-RP (a resistant lab- strain from Crete) (Emmanouil et al., 2006), which identical with this investigation in pyrethroid resistant-lab strain from Egypt.

The level of resistance conferred by each of them is difficult to infer. We are currently undertaking experiments to separate the two mutations, as well as to obtain susceptible whiteflies of similar genetic background, to evaluate the exact level of the resistance conferred by each mutation and their impact (if any) on fitness. As in many agricultural pests, showing that whiteflies which carry the V929 (or I959) alone are viable, in line with previous studies (Morin et al., 2002 and Bass et al., 2004).

Horowitz et al.,(2003) suggested that although B-type may survive better than Q-type B. tabaci under untreated conditions, the faster occurrence and development of resistance in $\mathrm{Q}$ biotype favours its predominance in areas with heavy insecticide pressure history. The classification of the highly resistant strains (field strain and lab resistant) whiteflies isolated from Behera Governorate as $\mathrm{Q}$ biotype, indicates that the use of insecticides may have increased the occurrence of these biotype in Egypt. However further studies are needed to explain the $\mathrm{B}$ and $\mathrm{Q}$ biotypes genetically isolation. Nevertheless, our data show little or no gene flow between $\mathrm{B}$ and $\mathrm{Q}$ biotypes of $B$. tabaci since the introduction of the widespread use of synthetic insecticides that target the para-type voltage gated sodium channel such as pyrethroids. 


\section{REFERENCES}

1. Abbott,W.S. 1925. A method of computing the effectiveness of an insecticide. J. Econ. Entomol., 18: 265-267.

2. Abdallah,M.D. 1991. A general view of the resistance problem of cotton pests in Egypt. Resist. Pest Manag. 3: 22-25.

3. Ahmadian, A., B. Gharizadeh, A.C. Gustafsson, F.Sterky, P.Nyren, M. Uhlenand and J.Lundeberg. 2000. Single-nucleotide polymorphism analysis by pyrosequencing. Anal. Biochem. 280, 103-110.

4. Alon, M., J. Benting, B. Lueke, T. Ponge, F. Alon and S. Morin. 2006. Multiple origins of pyrethroid resistance in sympatric biotypes of Bemesia tabaci (Hemiptera:Aleyrodidae). Insect Biochem. and Mol. Biol. 36: 71-79.

5. Atkinson,S.E. 2002. Interaction of pyrethroids with the voltage gated channel, Ph.D. thesis, University of Nottingham 144

6. Bass, C., I.Schroeder, L.M. Turberg, M.S. Field and Williamson. 2004. Identification of mutations associated with pyrethroid resistavce in the para-type sodium channel of the cat flea, Ctenocephalides felis, Insect Biochem. and Mol. Biol. 34: 1305.

7. Denholm, I., M. Cahill, T. J. Dennehy and A.R. Horowitz. 1998. Challeges with managing insecticide resistance in agricultural pests exemplified by the whitefly Bemisia tabaci . Philos. Trans. R. Soc. Land. Ser. B-Biol. Sci. 353:1757.

8. Emmanouil, R., A. Tsagkarakou and J. Vontas. 2006. Identification of mutations in the para sodium channel of Bemisia tabaci from Crete, associated with resistance to pyrethroids. Pestic. Biochem. and physiol. 85: 161-166.

9. Farghaly,F.S. 2005. Studies on profenofos and thiamethoxam resistance in whitefly, Bemesia tabaci Ph.D. thesis, Cairo University.

10. Hafez El Kady and Gregor J. Devine. 2003. Insecticide resistance in Egyptian populations of the cotton whitefly Bemisia tabaci (Hemiptera:Aleyrodidae). Pest Manag Sci. 59: 865-871.

11. Horowitz,A.R., I.Denholm, K.Gorman, J.L.Cenis, S.Kontsedalov and I.Ishaaya. 2003. Biotype Q of Bemisia tabaci identified in Isreal. Phytoparasitica 31: 94-98.

12. Martinez-Torres, D., A.L.Devonshire and M.S. Williamson. 1997. Molecular studies of knockdown resistance to pyrethroid: cloning of domain II sodium channel gene sequences from insects. Pestic. Sci. 51: 265-270.

13. Morin, S., M.S.Willamson, S.J.Goodson, J.K.Brown, B.E.Tabashnik and T. J. Denneny. 2002. Mutations in the Bemesia tabaci para sodium channel gene associated with resistance to a pyrethroid plus organophosphate mixture. Insect Biochem. and Mol. Biol. 32: 1781-1791. 
14. Prabhaker, N., D.L. Coudriet and D.E. Meyerdirk. 1985. Insecticide resistance in the sweetpotato whitefly, Bemesia tabaci(Hemiptera :Aleyrodidae). J. Econ. Entomol., 78 : 748-752.

15. Roditakis, E., A. Tsagkarakou and J. Vontas. 2006. Identification of mutations in the para sodium channel of Bemisia tabaci from Crete, associated with resistance to pyrethroids. Pesticide Biochem. and physiol. 85: 161-166.

16. Sobiha, A.K., Z.H. Zidan, M.M. Mowafy and A.S. Marzouk. 1997. Effect of certain insecticides regims on some sucking insects and natural enmies inhabiting cotton plants. Ann. Agric. Sci. 42: 665-674.

17. Soderlund, D.M. and D.C. Knipple. 2003. The molecular biology of knockdown resistance to pyrethroid insecticides, Insect Biochem. and Mol. Biol. 33: 563. 


\section{تحديد الطفرات فى قناة الصوديوم المرتبطة بمقاومة الاببابة البيضاء}

\section{لمركبات البيرثرويدز}

سيدة فاروق فرغلى هالة محمد (بو يوسف محمد سنجاب يحيى فتحى السيد غنيم

$$
\text { الدعدل المركزى للمبيد/ت - مركز البحوث النزراعبة - الدقى - الجيزة - مصر }
$$

تعتبر قناة الصوديوم هى الموقع الأساسى لتأثير مبيدات البيرثرويدز، ففى بعض الحشرات

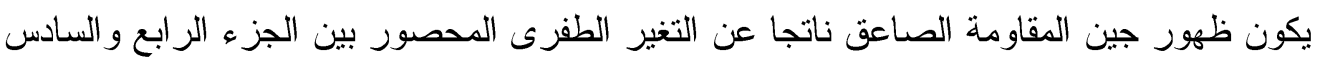
( II S 4 - 6 )

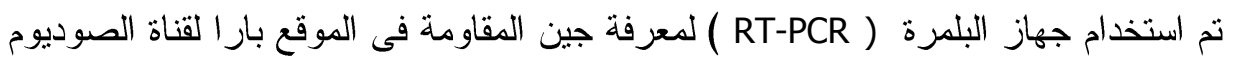

وذللك لكلا من السلالة المعملية ( الحساسة ) ، وسلالة الأباء بعد جيل واحد من المعاملة بمركب المبن

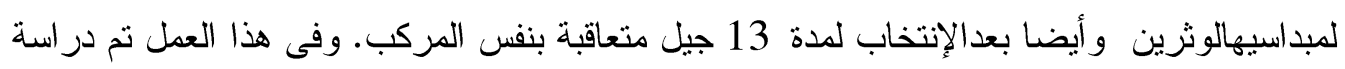

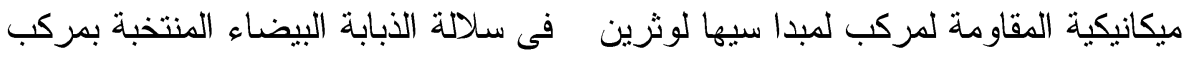

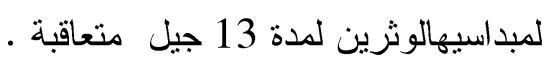

أوضحت نتائج التحليل الجينى للشريط الور اثى فى عينات كلا من السلالة المعلية وسلالة الاباء و السلالة المقاومة وجود نوعين من الأحماض الأمينية ظهرت فيهما إستبدالات مقارنة بسلالة

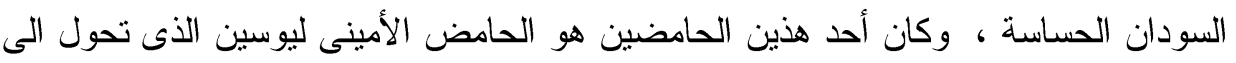

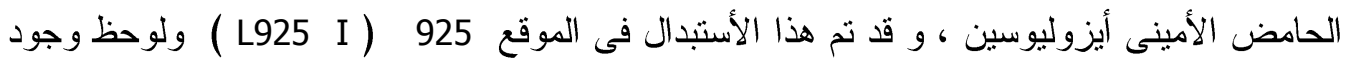
الأليل r1-Q1 الموجود في بنك الجينات برقم DQ205206 وذللك في عينات كلا من السلالة المعملية

وسلالة الآباء ، وكان الحامض الأمينى الثانى الذى حدثت لة إستبدالات فى جين المقاومة للابنابة

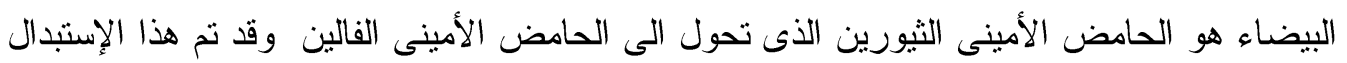

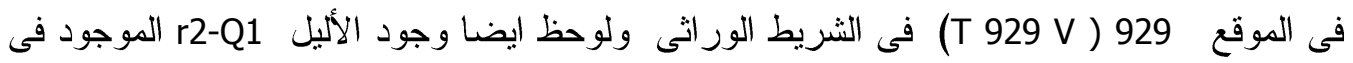
بنك الجينات برقم DQ205207 وذلك فى عينة السلالة المقاومة. 